\title{
On strengthening the management of special funds for universities
}

\author{
Lv Zhi xue $\mathrm{e}^{1, \mathrm{a}}$ \\ ${ }^{1}$ Jilin Jianzhu University, Planning and Finance department,Changchun,china \\ alvzhixue_2007@sina.com
}

\begin{abstract}
With the deepening financial reform, when universities applying for special funds need to change the concept, timely establish of special funds for scientific management system. This article start with the universities reporting of special funds, using the process of concluding the major management problems. Propose to solve universities special funds problems existing in the management strategies. In order to strengthen the management of special funds.
\end{abstract}

Keywords- University, Special funds, Management.

\section{I.INTRODUCTION}

University special funds is the government arrange the outside the specified basic expenditure items and special purpose funds. Main focus on key subject construction funds, key laboratory of construction funds, funding to improve school conditions, technology three funds, etc. With the increase of investment in higher education in every year, special funds proportion of the total funds also increased year by year. Due to timeliness of special funds, strong policy, earmarking requirements, therefore, it is difficult to use the money and always embezzlement or taking signs are other where, it has lost the significance of financial investment in special funds. Over time, it will affect the development of universities and development of higher education.

\section{II.CURRENTLY,THE MAIN PROBLEMS IN THE MANAGEMENT OF SPECIAL FUNDS IN UNIVERSITY}

Management of special funds in university is on the special funds from the project, reporting, approval, disbursement of funds to use and completion of the project supervision and management of the entire process, requires special funds on real project, complete the budget, Funds to be earmarked. When the project is completed need to performance evaluation, tracking, and accountability. The special fund management issues are reflected in every aspects, for example:

\section{A.Problems in university special funds in the reporting process.}

The problems in universities reporting in special funds. At first, insufficient to declare the project, according to the traditional way, during the application of special funds from finical department, the applicants do not often consider the actual need, and make the false application, in order to get funds; Secondly, the project budget is yet in the rough and not scientific enough, When they make the budget of the program they often set up the concrete amount of funds and then determine the budget. Reporting budget funds are often blind to expand more than the actual need,When financial audits the project funds will be cut off part of funds according to the actual situation. Then they use more money on bigger project and less money on small project. Finally, report the same project is been serious problem, this is because project library is not updating timely or man-made factors. Finance department face to thousands of special funds every year is unable to know how much difference on special funds between one year to another which will inevitably lead to duplication of investment and reduce the efficiency of special funds.

\section{B.The problems in the using of special funds.}

Using special funds should be strictly in accordance with the budgeting, however, misappropriation of funds is always exist in actual use. Some factors are inevitable, due to the special financial reporting in the beginning of each year and the majority of project expenditures has occurred when funds release at the end of every year, then that will be the end of the fiscal year. Plus special funds required to pay up within the stipulated time, otherwise the money will be take back, there for the school need spending rest of money at the end of the year. There are some human factors which is not paid the special funds by the project budget ,such as organizing meetings of the transport fee ,accommodation fee, telephone charges, mailing fees required to reimbursed. However these are difficult to grasp that which is the meeting costs. Like the budget for the purchase of materials and equipment used in labor costs and so on. Now days, in government purchase list need buy over 10thousands and 20thousands equipments, but part of the purchase by the government do not conform to the standards and serious waste of money.

\section{C.The problems in the results of inspection of special funds}

Serious phenomenon of special funds on treasure investment, depreciate management ,treasure budget arrangement, depreciate tracing accountability in the process of using. After the end of the project, universities should use of quantitative evaluation analysis and basis on the investment summarized and explained the project. The financial department should check and audit on one of the large special important work. In favor of application for special funds on next year and subsequent years. However, the actual implementation process is often due to financial department supervision not strong and lack of special funds for university management system construction, the person in charge of project funds ideology not strong, then lead to the process of project results tend to form. 


\section{III.COUNTERMEASURES TO THE PROBLEM OF FUNDS MANAGEMENT IN UNIVERSITIES}

\section{A.To raise ideology, change the traditional concept}

The main income of universities relies on financial allocation of government at present. How to manage finances and make good use of the funds to be the important part can not be ignored to the administrators along with the increasing investment of government in education. Special funds of financial management are getting increasing tightly, it requires universities not only to use money wisely but also to get huge benefits. It makes all the staff in universities improve the ideology, change the traditional concept. We must comply with to seek the truth from the facts principle when applying special funds.. We must use the funds according to the budget and guarantee the funds are used for specified purposes only. Make full use of the opportunities brought by the financial reform and development, handle the relationship between full use of special funds and long-term development and universities correctly. Establish an effective management system and operation mode, use the financial resources rationally to promote the healthy development of university.

\section{B.To improve the management system, solid management foundation}

Universities should establish perfect rules and regulations together with authorities from all aspects of special funds including project approval, disbursement of funds, usage and management of funds, as well as supervision afterwards. First, to establish a reporting system for the project and a strict examination and approval system to ensure that the project budge and goals will be reasonable and satisfy the needs and demand of the development of education. Second, establish management systems and usage of special funds, including using the funds and it's matching funds with standard. Government procurement should be strictly in accordance with government procurement requirements. Finally, to improve the supervision system of special funds including special funds project audits, prepare audit of special funds budget, special funds to perform audits.

\section{C.To achieve performance evaluation, strengthen financial supervision}

The financial department should promote the special fund performance management gradually, innovation management system. To put the whole process of performance management concepts into the management of special funds, make the preparation of the budget, implementation, monitoring together become an integral part of the special funds management. Be "targeted budgeting, budget execution supervised the project has completed the evaluation and its results and feedback, the feedback of the results to the use of" budget performance management model. Meanwhile, the government must strengthen supervision, the first is to examine the performance goals, adjusted it to meet the requirements before go the next process; Second is to strengthen the supervision of the implementation process, to grasp the achievement of project objectives, Finally, pay high attention to the organic performance evaluation. Organize experts evaluate the key projects or major projects and feedback the results timely and enhance application of performance evaluation results, establish a system to combine of evaluation results and budget management.

\section{IV.CONCLUSION}

Administrator in Universities should change the traditional ideas, improve the system construction of special funds management, strengthen auditing and supervision to ensure to get the maximize effectiveness in special funds. Improving the management of special funds is of great benefit to university financial resources and healthy development of higher education, meanwhile to be the trend of government information disclosure. Meanwhile administrator in university should communicate with the financial authorities, education authorities actively to arrange more budget financial allocations, less special funds in the fiscal budget arrangements, try to give universities more autonomy. I believe, universities will arrange and prepare the budget according to the principle "balance, focused assurance, actively and steadily thrift" so that university could use the capital sources from a variety of channels and deployment flexibility, and get the maximize economic and social benefits from funds invested.

\section{REFERENCES}

[1] Du Gujun, Ziyuan, Study on Fiscal Management of Special Funds in Universities [J] China Electric Power Education 2010,7:185-186

[2] Qin Hong, Yan Wen, Study on Special Fund Expenditure Performance Evaluation of Universities [J] Research and Exploration 2009,6:35-36

[3] Li Shiyou, Li Ping, Probe Fund Projects of Special Monitoring System of University [J] Financial and Management 2010,2:26-27

[4]Gao Lasheng.The Limitation and Innovation of Financial Management Patterns in Colleges. $[\mathrm{J}]$.Communication of Finance and Accounting. 2005:34-36

[5]Cheng Xiaojia. Some Thinking of Improving the Account System of Public Institution in China. [J].Current Affairs and Accounting. 2005,12:4-6

[6]Wang Yubin. The Analysis of the Rigid Management of Expense Budget in Colleges. [J].Studies of Finance and Accounting in Education, 2006,3:18-20 